\title{
DOENÇA DE GAUCHER TIPO I: RELATO DE CASO
}

\author{
Alessandra Guerra Godoy 1; Isnard Elman Litvin 2; Bruna Schena 3; \\ Juline Isabel Leichtweis Balensiefer ${ }^{4}$; Letícia Baumgarten \\ Rodrigues ${ }^{5}$
}

\section{Resumo}

A Doença de Gaucher (DG) é uma desordem genética autossômica recessiva resultante de mutações patogênicas do gene que codifica a enzima glicocerebrosidase, resultando em acúmulo de glicocerebrosídeos nos fagócitos e no sistema nervoso central (SNC). Fisiopatologicamente, as células de Gaucher caracterizam-se por células fagocíticas distendidas, encontradas no baço, fígado, medula óssea, entre outros. As células têm aparência de anéis de sinete com "lenço de papel amassado". O lipídio armazenado nos lisossomos transborda para o citoplasma e a glicosilceramida é convertida em glicosilsphingosine, havendo um aumento de seus níveis séricos. A produção desses lipídios bioativos envolve outros tipos de células, como o sistema imune, que secreta citocinas que são responsáveis pela destruição óssea e participarão na iniciação e propagação da patogênese da doença.

Paciente OTSL, 46 anos, feminina iniciou investigação de anemia em 2011. Em outubro realizou biópsia de medula óssea que evidenciou escassa hemopoiese e infiltração da medula por numerosos histiócitos, compatível com doença de Gaucher. Em novembro de 2014 iniciou investigação de ferritina persistentemente elevada. A biópsia de fígado mostrou infiltrado reacional e esteatose leve e colestase discreta. Presença de agregados de células de Kuppfer aumentadas de tamanho, com citoplasma "enrugado", consistente com doença de acúmulo lisossomal Tipo 1 infiltrando parênquima hepático.

A DG pode ser assintomática ou sintomática, sendo definida em três diferentes tipos de acordo com os sinais clínicos, presença e taxa de progressão ou ausência de doença neurológica. A DG Tipo 1 causa esplenomegalia, doenças do sangue, complicações ortopédicas e ausência de 
sintomas neurológicos. O diagnóstico é baseado em biópsias de medula óssea e fígado e na microscopia de luz.

\footnotetext{
${ }^{1}$ Médica patologista, phD em Biotecnologia, professora adjunta da Universidade de Caxias do Sul-RS. aeggodoy@gmail.com

${ }^{2}$ Médico patologista, mestre em Cirurgia, professor auxiliar da Universidade de Caxias do Sul RS. lelitvin@terra.com

${ }^{3}$ Graduanda em Medicina na Universidade de Caxias do Sul - RS. bruna_1209@hotmail.com

${ }^{4}$ Graduanda em Medicina na Universidade de Caxias do Sul - RS. julinelb@hotmail.com

5 Graduanda em Medicina na Universidade de Caxias do Sul - RS. leticia130192@hotmail.com
} 